\title{
Urban Tree Growth and Longevity: An International Meeting and Research Symposium White Paper
}

\author{
Rachel Leibowitz
}

\begin{abstract}
Executive Summary. Researchers from around the world gathered at The Morton Arboretum (Lisle, Illinois, U.S.) in September 2011 to share their experiences and knowledge on the topic of urban tree growth and longevity. A roundtable discussion was held at the end of the second day's program, during which attendees discussed the state of current research in these areas and identified needs for future research. Four distinct subgroups were identified within the broader topic of urban tree growth and longevity: tree production; site design and tree selection; tree and site management; and the need for descriptive studies. Throughout the discussion, it became clear that there must be greater collaboration among researchers investigating tree growth, increased investment in long-term studies, the development of a clearing house for information, and the fostering of productive partnerships between the governmental, industry, and academic sectors. To strengthen the impact of urban tree growth research on the tree care industry, results and conclusions must be summarized and distributed through suitable means for a variety of audiences, which might include federal, state, and local governments; property owners and consumers; nurseries and growers; tree care and other green industry professionals; and urban planners, civil engineers, and landscape architects. To this end, the Urban Tree Growth \& Longevity Working Group has been established to support communication between researchers and professional practitioners, enrich scientific exchange, and enhance the quality, productivity, and timeliness of research on tree growth, longevity, and mortality.
\end{abstract}

The general public has become more aware of the environmental, economic, and social benefits associated with urban trees, in no small part due to the cumulative efforts of research institutions and universities, government agencies, and both private and nonprofit organizations. This newfound awareness, together with the latest information on climate change, has resulted in decisions to more substantially fund urban forest planting and management programs in many cities. Throughout the world, cities are committing to plant millions of trees under broad planning initiatives; in the United States, million-tree programs are underway in New York City, New York; Philadelphia, Pennsylvania; Denver, Colorado; Salt Lake City, Utah; and Los Angeles, California; while Sacramento, California has plans to plant five million trees (Young 2011). Perhaps most astonishing is Mexico City, Mexico, which has announced its goal to plant one billion trees over four years.

Many of these millions of new trees will not survive to maturity, when anticipated environmental benefits are greatest, due to a variety of factors or conditions. For some, it may be because of inadequate or compacted soils in their urban locations; for others, it may be due to abnormal growth that has gone unchecked, or because of poor planting practices with deleterious effects on tree roots. Lack of appropriate care and maintenance or inadequate monitoring also may be the cause of urban tree mortality. Although researchers are addressing these issues in laboratories, nurseries, and urban settings throughout the world, the transfer of this knowledge to growers, municipalities, private property owners, and tree care specialists is often slow or difficult. Determining urban tree life expectancies requires long-term data (Roman and Scatena 2011). Providing these important players with new science that answers the most important questions in an understandable fashion is a challenge that must be met to keep urban trees healthy.

To foster productive discussions on future needs for research in the areas of urban tree growth and longevity, and to share current findings by international scholars and practitioners, a research symposium was held September 12-13, 2011, at The Morton Arboretum (Lisle, Illinois, U.S.). The two-day event was organized with presentations on four topics, each with a keynote speaker and three to five additional speakers. At the conclusion of these presentations on the afternoon of the second day, attendees gathered for a roundtable discussion in which the four topics were further discussed, and research priorities for each were listed and ranked. All conference participants were encouraged to contribute to this conversation, with arborists, planners, students, and researchers sharing their insights. Greg McPherson, research forester with the United States Department of Agriculture Forest Service (USDA Forest Service) Pacific Southwest Research Station in Davis, California, facilitated the discussion. The research priorities established for each of the four topic areas will be the building blocks of the research agenda for the new Urban Tree Growth \& Longevity Working Group under the Arboricultural Research and Education Academy, a professional affiliate organization of the International Society of Arboriculture.

The four topic groups for this international research symposium, as presented in lectures and poster displays at The Morton Arboretum's Thornhill Education Center, included:

1. Descriptive Studies of Tree Growth, Longevity, and Mortality

2. Roles of Tree Production and Sales on Tree Growth and Longevity 
3. Roles of Site Design and Tree Selection on Tree Growth and Longevity

4. Roles of Tree and Site Management on Tree Growth and Longevity

\section{TOPIC \# 1: DESCRIPTIVE STUDIES OF TREE GROWTH, LONGEVITY, AND MORTALITY}

Greg McPherson and Paula Peper, Ecologist with the USDA Forest Service, co-authored the keynote presentation for this topic, "Tree Growth Studies: Propelling Arborists to New Heights." Researchers and presentations in this first group included Chris Martin (Arizona State University), "Tree Growth and Health in Phoenix"; Robert Fahey and Marlin Bowles (The Morton Arboretum), "Linking Composition, Structure, and Productivity Across Chicago's Urban Forest"; Lara Roman (University of California, Berkeley), "Urban Tree Mortality Rates: Concepts from Demography"; Bryant Scharenbroch (The Morton Arboretum), "A Soil Quality Index for Urban Trees"; and Julia Bartens (University of California, Davis), "Live Oak Growth in the Streets of Jacksonville, Florida: Can We Predict Its Future?"

During the roundtable discussion, participants identified common threads among the presentations and needs for future research. These five U.S.-based descriptive studies represented very different geographic regions, from Florida to the Midwest, and from Northern California to the arid Southwest, yet all of the researchers were committed to:

* investigating relations between trees and people

* improving quantitative assessment of tree growth, mortality, and longevity

* $\quad$ integrating their research into improved arboricultural practices

* understanding human perception of "improved" site designs in urban areas

Studies on urban tree growth and longevity are few and rather fragmented. Data collection for these studies relies heavily on regional networks and the International Tree Failure Database. Remote sensing techniques proved useful for collecting information in such studies, but their development and application could be more widespread. Analyses of these studies suggests that the development of coordinated databases that could be mined to identify correlations and causes of urban tree growth, longevity, and mortality, would be of a tremendous benefit to current and future researchers. Likely partnerships to foster further research and greater exchange of information were suggested between the nursery industry/growers and providers of tree care services, statisticians, physiologists, pomologists, and foresters. Potential resources for funding and collaboration were identified as being most likely among governmental agencies, corporations, and the tree care and growers' industries.

Symposium attendees provided many comments, questions, and suggestions for further investigation and development of descriptive studies. It was suggested that the relationship or influence of tree management on soil carbon flux be investigated. A standardized database of information gathered during large-scale tree plantings and maintenance programs should be established and shared by research- ers, practitioners, and citizens of municipalities. Decisions of what is important for future research and technology development should be based upon exchange between existing networks of tree planters, managers, and scientists.

Future research priorities for descriptive studies were ranked in the following order, with a tie for fourth place:

1. Determine the value of an urban site index and the next steps in its development.

2. Establish a comprehensive, standardized monitoring network for long-term planting projects that includes data on social, biological, and management issues.

3. Improve collaboration and data sharing among researchers.

4a. Standardize data to better facilitate sharing of information.

4b. Determine an appropriate tree response variable for tree growth, health, and belowground functioning.

\section{TOPIC \#2: ROLES OF TREE PRODUCTION AND \\ SALES ON TREE GROWTH AND LONGEVITY}

Edward F. Gilman, professor in the University of Florida's Environmental Horticulture Department, authored the keynote presentation for the second topic, "Nursery Production Strategies Impact Tree Longevity and Performance-Don't They?" Researchers and presentations in this group-addressing the roles of tree production and sales on tree growth and longevity-included Ed Mulrean (Arid Zone Trees, Phoenix, Arizona), "Propagation and Production for Dispersed Root Systems"; Matthew Stephens (New York City Department of Parks and Recreation), "What Should We Plant? New York City's Plan to Diversify Its Urban Forest One Tree at a Time"; and Henrik Sjöman (Swedish University of Agricultural Sciences), "Habitat Studies as a Selection Model in the Search for Future Urban Trees."

During the roundtable discussion it was noted that relatively few people are working on proper tree production techniques. The need to reduce the carbon footprint of containers (polypropylene plastic) also was discussed. Whether from the perspective of a producer or consumer, it was acknowledged that urban tree survival must be improved, generally, for both container and ball-and-burlap trees. The question then arose: over how long a period of time would a difference be observed in the survival rate among containerized or balled-andburlapped trees? It was stated that increased root tips should be closer to the soil surface, yet a question was raised regarding when new roots stop being generated from the root flare. A need for a deeper examination of native trees was discussed, including the fine root structure of many native species, as well as more studies on the significance of tree size at planting and its relationship to the tree's successful establishment and survival. Nurseries and growers have opportunities to identify, at the earliest stages, the factors that may predict a tree's health and longevity; can nurseries, through genetic engineering, produce superior specimens of urban trees? Selections for tree plantings can and should be based upon environmental tolerances, with new selections carefully screened before planting to ensure the greatest chance for survival. 
Potential outcomes of the research discussed:

* enhancing coordination and cooperation with growers regarding best practices for the development of stock, especially for large planting projects

* development of state-specific standards for nursery stock

* opportunities for partnerships between arboricultural researchers, practitioners, and growers

Future research priorities for investigating the roles of tree production and sales on tree growth and longevity were ranked in the following order:

1. Investigate the importance of small, fibrous roots in a root ball, relative to tree growth and mortality rates.

2. Species-specific root architecture issues should be studied.

3. Genetic improvements in tree production should be sought.

4. Identify rooting zones at transplant time.

5. Determine the optimal planting depth for a given tree in typical urban conditions.

6. Establish the extent to which circling roots can grow without causing irreparable damage to a tree.

\section{TOPIC \#3: ROLES OF SITE DESIGN AND TREE} SELECTION ON TREE GROWTH AND LONGEVITY

For the third session of the symposium, the keynote presentation, "Site Design and Tree Growth," was provided by Susan Day, assistant professor in the departments of Horticulture and Forest Resources and Environmental Conservation at Virginia Tech. The roles of site design and tree selection on tree growth and longevity were further discussed in presentations by the following researchers: E. Thomas Smiley (Bartlett Tree Research Laboratory), "Growing Trees in an Urban Plaza Environment"; Alan Siewert and Stephanie Miller (Division of Forestry, Ohio Department of Natural Resources), "Urban Site Index for Urban Forest Planning"; and Jason Grabosky (Rutgers University), "An Organizational Approach to Urban Tree Management and Longevity."

In summarizing the current state of the roles of site design and tree selection on the symposium's second day, the need to predict ultimate tree performance was emphasized. One approach is examining the genetic and phenotypic characteristics of veteran trees that exhibit unusual longevity.

Discussants at the roundtable session offered many comments and questions for further research on the effects of site design and tree selection on urban tree health and survival. Researchers should develop partnerships with municipalities and tree planting groups, whether ad hoc neighborhood associations or established tree planting nonprofit organizations, to share information on proven practices and to begin new research. Studies should be undertaken that investigate the relationship of economic and sociological variables to tree growth and survival. Researchers also should take the initiative to integrate the results of their research into local tree ordinances. For example, if researchers know the best planting depths or soil conditions for trees in a parking lot, they should reach out to lo- cal communities to incorporate this information into their tree planting and maintenance practices. Participants also mentioned the need for further study into the architecture of root systems and potential advances toward improving tree health and longevity through genetic engineering. Lastly, they acknowledged the need for development of a common language for effective communication between all stakeholders, and stated that this should be an imperative of the Urban Tree Growth and Longevity Working Group.

Future research priorities for investigating the roles of site design and tree selection on tree growth and longevity were ranked in the following order:

1. Accurately predict tree performance for different ecosystem services, given differences in site conditions, species, management, and other variables.

2. Analyze or estimate the return on investment for different levels of site preparation.

3. Determine the effects of storm water retention on tree health (bioretention).

4. Investigate how planting type (i.e., bare root, field grown, and container) influences growth, survival rates, and costs of production, planting, and care.

5. Increase the number of long-term studies of impacts of site design and tree selection on growth, longevity, and health.

\section{TOPIC \#4: ROLES OF TREE AND SITE MANAGEMENT ON TREE GROWTH AND LONGEVITY}

James Clark, an ISA Certified Arborist and the Vice President of HortScience, Inc., of Pleasanton, California, delivered the keynote presentation, "Making the Most of What Science Offers Us," for the final session of the symposium. Researchers and presentations for this fourth topic-the roles of tree and site management on urban tree growth and longevityincluded Alessandro Pestalozza (Dendrotec, Monza, Italy), "Roadwork and Street Trees: The High Cost of Coexistence"; Alessio Fini (University of Florence, Italy), "The Effect of Repeated Pruning Cycles on Tree Structure and Physiology of Sycamore Maple Depends on Pruning Method"; Gary Watson (The Morton Arboretum), "Tree Planting Depth Impacts Growth"; and Nina Bassuk (Cornell University), "Rooting Volume and Tree Growth Responses in the Urban Environment."

In summarizing the current state of research, it was noted that models and assessment methods must play an important role in future scientific studies. Demographic studies should include tree survival, mortality, and removal patterns. Researchers should examine species' response to disturbances as well as specific management practices, such as the use of recycled water for irrigation. It was suggested that further study is needed on the relationship between wood decay and carbon sequestration. Of particular importance, the effectiveness of assessment tools must be verified. Forging partnerships between municipalities and researchers in academic settings was recommended. One recommendation was to establish an information clearinghouse on the roles of tree and site management-perhaps following the International Tree Failure Database model wherein information is standardized for ease 
of use among all stakeholders. The value of long-term studies was emphasized; such studies are critical to our understanding of how trees thrive over their lifetimes in urban settings.

During the roundtable discussion, symposium participants had many comments and suggestions for future research on this final topic, including ideas for new partnerships and models. For example, researchers might partner with developers and landscape architects to monitor long-term performance of their projects. The Landscape Architecture Foundation is encouraging such collaboration through its Case Study Investigation program and Landscape Performance series (www.lafoundation.org/research/case-study-investigation). Again, many noted the great need to standardize data collection practices, particularly so that nonprofit organizations and community volunteers can take part in this research work. Researchers should establish and maintain partnerships with arborists, and also work to minimize lack of communication, planning, or cooperation between tree growers, landscape designers, and builders/developers-even if that means providing incentives for these different stakeholders. An effective communication network is needed to improve the exchange of information among these parties.

Future research priorities were ranked in the following order:

1. Understand how tree management influences ecosystem services.

2. Investigate how different trees/species respond to disturbance, stress, and management treatments.

3. Expand the scope of demographic studies on tree survival, mortality, and removal patterns.

4. Examine best practices for trees that are alive, but show slow growth, or no growth, due to poor soils.

5. Verify the accuracy and evaluate the cost-effectiveness of different site and tree assessment tools.

\section{CONNECTING THEMES AND CONCLUSIONS}

Several themes were repeated throughout the symposium. Many participants agreed that there must be greater collaboration between researchers investigating all aspects of tree growth and longevity. A greater appreciation or understanding of the value of long-term studies must be fostered not only among the research community, but among other stakeholders as well. A clearinghouse for monitoring information should be established for the use of researchers, designers and developers, arborists, nonprofit organizations, and consumers. The database should foster use of standardized terminology and measurements.

To strengthen the impact of urban tree growth research on the tree care industry, results and conclusions must be effectively summarized and distributed to a variety of audiences, which might include federal, state, and local governments; property owners and consumers; nurseries and growers; tree care and other green industry professionals; and urban planners, civil engineers, and landscape architects. The Urban Tree Growth and Longevity Working Group has been established toward this end, to support communication between researchers and professional practitioners, enrich scientific exchange, and enhance the quality, productivity, and timeliness of research on tree growth, longevity, and mortality. The goal of this new group is to implement a coordinated approach to provide tree care pro- fessionals and tree owners with the information they need to make informed decisions that will improve tree performance.

Information for the working group may be found online (urbantreegrowth.org).

Presentations and proceedings of the 2011 research symposium held at The Morton Arboretum may be found online as well (www.masslaboratory.org/urban-tree-growth-longevity-conference-2011.html).

\section{LITERATURE CITED}

Roman, L.A., and F.N. Scatena. 2011. Street Tree Survival Rates: Meta-analysis of Previous Studies and Application to a Field Survey in Philadelphia, PA, USA. Urban Forestry \& Urban Greening 10:269-274

Young, R. 2011. Planting the Living City. Journal of the American Planning Association 77(4):368-381.

Rachel Leibowitz

Science and Research Manager

International Society of Arboriculture

2101 W. Park Court

Champaign, Illinois 61821, U.S. 
Résumé. Les chercheurs de partout dans le monde se sont rencontrés à l'Arboretum Morton (Lisle, Illinois, États-Unis) en septembre 2011 afin de partager leurs expériences et leurs connaissances à propos de la croissance des arbres urbains et leur longévité. Une table ronde de discussion s'est tenue à la fin de la seconde journée durant laquelle les personnes présentes ont discuté de la situation de la recherche en cours sur ces sujets et des besoins en recherche future. Quatre sous-groupes distincts ont été identifiés parmi le vaste domaine de la croissance des arbres et de leur longévité: la production d'arbres, l'aménagement du site et le choix des arbres, la gestion des arbres et de leur environnement, et le besoin envers des études descriptives. Au-travers des discussions, il est devenu évident qu'il devait y avoir une meilleure collaboration entre les chercheurs de ce domaine, des investissements accrus pour des études à long terme, le développement d'un organisme de diffusion de l'information, ainsi que de favoriser la création de partenariats productifs entre les secteurs gouvernemental, industriel et académiques. Pour renforcer l'impact de la recherche sur la croissance des arbres pour l'industrie arboricole, les résultats et les conclusions doivent être compilés et distribués par des moyens divers et efficaces auprès d'une variété d'auditeurs qui incluent les gouvernements locaux, fédéral et d'états, les propriétaires et les consommateurs, les pépiniéristes, les entrepreneurs en arboriculture et les autres professionnels de l'industrie, les planificateurs urbains, les ingénieurs civils et les architectes paysagistes. À cette fin, un Groupe de travail sur la croissance et la longévité des arbres urbains a été créé dans le but de favoriser la communication entre les chercheurs et els professionnels pratiquants, d'enrichir les échanges scientifiques ainsi que pour améliorer la qualité, la productivité et l'opportunité de la recherche sur la croissance des arbres, leur longévité et leur mortalité.

Zusammenfassung. Forscher aus der ganzen Welt versammelten sich im September 2011 im Morton Arboretum in Lisle, Illinois, USA, um ihre Erfahrungen und ihr Wissen über den Themenkreis: Urbanes Baumwachstum und Langlebigkeit miteinander auszutauschen. Am Ende des zweiten Programmtages fand eine Diskussion am Runden Tisch statt, wobei die Anwesenden den Stand der gegenwärtigen Forschung in diesem Bereich diskutierten und die Anforderungen an künftige Forschung herausarbeiteten. Innerhalb des breiten Themenkreises: Urbanes Baumwachstum und Langlebigkeit wurden vier unterschiedliche Unterthemen identifiziert: Baumproduktion, Standortgestaltung und Baumartenwahl, Baum- und Standortmanagement und den Bedarf an beschreibenden Studien. Während der Diskussion wurde klar, dass es einer größeren Kollaboration innerhalb der Erforschung des Baumwachstums, wach- sender Investitionen in Langzeitstudien, der Entwicklung einer Informationszentrale und der Förderung produktiver Partnerschaften zwischen Verwaltung, Industrie und dem Ausbildungsbereich bedarf. Um den Einfluss von Forschung an Baumwachstum im urbanen Bereich auf die Baumpflege-Industrie zu stärken, müssen die Ergebnisse und Schlussfolgerungen summiert und durch geeignete Medien für ein breites Publikum zugänglich gemacht werden, einschließlich Bundes- Länder- und Kommunalverwaltungen, Grundstückseigner und Konsumenten, Baumschulen und Züchter, Baumpflege- und andere Landschaftsbau-Industrie, Städteplaner, Ingenieure und Landschaftsarchitekten. Am Ende etablierte sich eine Arbeitsgruppe: Urbanes Baumwachstum und Langlebigkeit, welche die Kommunikation zwischen Forschern und professionellen Praktikern unterstützen, den wissenschaftlichen Austausch bereichern und die Qualität, Produktivität und Aktualität der Forschung in Baumwachstum, Langlebigkeit und Sterberate verbessern soll.

Resumen. Investigadores de todo el mundo se reunieron en el Morton Arboretum (Lisle, Illinois, Estados Unidos) en septiembre de 2011 para compartir sus experiencias y conocimientos sobre el tema del crecimiento y longevidad de los árboles urbanos. Se celebró una mesa redonda al final de la segunda jornada, durante la cual los asistentes discutieron el estado de la investigación actual en estas áreas e identificaron necesidades para futuras investigaciones. Se vieron cuatro subgrupos distintos dentro del tema más amplio de crecimiento y longevidad de los árboles urbanos: producción de árboles; diseño de sitio y selección de árbol; árbol y manejo del sitio; y la necesidad de estudios descriptivos. Durante el debate, quedó claro que debe haber una mayor colaboración entre los investigadores sobre el crecimiento del árbol, mayor inversión en estudios a largo plazo, el desarrollo de un centro de intercambio de información y el fomento de alianzas productivas entre gobierno, industria y sector académico. Fortalecer el impacto de la investigación sobre el crecimiento del árbol urbano en la industria de cuidado de árbol. Los resultados y conclusiones se deben resumir y ser distribuidos a través de medios adecuados para una variedad de audiencias, que podrían incluir a los gobiernos federales, estatales y locales; los propietarios y los consumidores; viveros y productores; empresas de cuidado de árboles y otros profesionales de la industria verde; urbanistas, ingenieros civiles y arquitectos paisajistas. Para ello, se estableció un grupo de trabajo sobre longevidad y crecimiento del árbol urbano que admite la comunicación entre los investigadores y profesionales, enriquece el intercambio científico y mejora la calidad, productividad y puntualidad de la investigación sobre el crecimiento, longevidad y mortalidad del árbol. 